\title{
弗素の歯牙に対する作用に就ての実験的研究
}

\author{
寉田賢 三 \\ 北海道大学医学部薬理学教室 (主任 真崎教授)
}

\section{Experimental Studies on the Effect of Fluorine on Teeth}

\author{
Kenzo Kubota \\ From the Department of Pharmacology, Faculty of Medicine, \\ Hokkaido University (Prof. T. Masaki)
}

It has already been demonstrated that fluorine has some influence on the tooth, but histological study was very rarely reported. The main purpose of this investigation was to make a histological study of the changes in the dentin of rabbit tooth which was administrated by fluorine intravenously.

The dentin stratification which might be induced by fluorine injection is so resistant to weak acid that it can be easily differentiated from other part of dentin under the microscope. It has been assumed that fluorine would deposit as calcium fluoride or fluoro-apatite.

The most part of injected fluorine seems to be excreted rapidly and the rest is effective to the odontoblasts. Very small amount of fluorine, therefore, is sufficient enough to cause the dental changes. Moreover it is believed that fluorine exerts a direct local action on the odontoblasts and that the changes observed in the dentin are not produced primarily by changes in blood calcium and phosphorus. It was also considered fluorine has no effect on the alkaline phosphatase in the dental pulp.

\section{緒言}

弗素は古くより一般原形質毒として重要な薬物 ではあつたが医学的脚光を浴びたのは所謂 Mottled teeth の発生因子として確認されてからで あり，近来缷刢抑制剤としての子防医学的応用が 極めて広範囲に進められて来た。然し弗素の中毒 症に就てはかなり詳細な研究が行われて居るにも

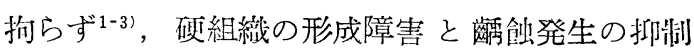
と云う全く相反した作用機転の相関性に就ては未 だ明確なる解答が与えられて居ない。歯牙に対す る作用は石灰化期に全身的に作用する場合と萠出 後乞の表面より局所的に作用する場合とではかな り異つた機序があるものと考えるが，殊に前者に
就ての研究は水道水の邛素化と関連して重要な問 題である。更にまたウラニウム分離に重要なる役 割を果すと云われる弗素は原子力工業の発展泮 つて種々なる化学工業的応用面が飛躍的に開拓さ れ，一般社会との接触機会は一層密接になつた。 就中, 工業中毒その他による人体への影響は今や 等閉に附せられない問題である。

そこで歯牙形成期に提取した州素が如何なる作 用機序で硬組織形成障害を惹起するかに就て実験 的研究を試みた。

\section{実験方法並びに実験成績}

\section{I. 歯牙硬組繶に現れる変化}

弗化物投与によつて硬組織形咸の障碍される。 
ことは睍に知られて居り，殊にエナメル質及び 象牙質に变質層板の出現することは Schour \& $\mathrm{Smith}^{4)}$, 岡田・三村 ${ }^{51}$, Euler \& Eichler ${ }^{6)}$ 及び Irving $^{7)}$ によつて観察されて居る。更に岡四・三 村 ${ }^{8)}$ は弗素注射日に相当する日周期層の耐酸性が 極めて大なることから, 硬組織生体染色の一法と して応用して居る。斯る変質層板出現の機序及び 石死代謝との関係に就て以下の如く組織学的検索 を進めた。

実験動物には全て成熟家鬼を使用し, 試料とし て下顎切歯象牙質を用いたが，必要に応じて他の 歯牙に就ても実験を行つた。

A）弗素変質層板の出現に就て

弗化物を静注し一定日後屠殺, 歯牙を横断研靣 乙て水洗, 乾燥後, この面の Methylmethacryate 転写膜に就て鏡検するに象牙質研磨面は平滑で層 状構造は認められない。次に研磨面を $\mathrm{pH} 4$ 程度 の醋酸緩衡液中に 5 分間浸漬して表面を軽く脱 灰した後の転写膜に就て観察すると, 構造は一変 して凹凹の層状構造を示し所謂像牙質の正常縞模

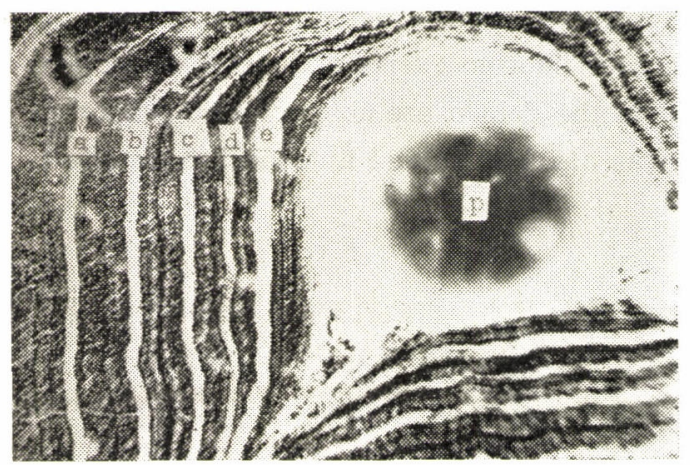

図 1 家鬼象牙質横断面

$\mathrm{a}, \mathrm{b}, \mathrm{c}, \mathrm{d}, \mathrm{e}$ ：弗素変質層板 $\mathrm{p}$ : 㐘蹢腔

様が見られる他に，殊に弗素注射日に相当する層 板は浮き彫りを施した如く明膫に現れて来る（図 1 )。この変質層板は極めて緻密な構造を呈し他の 層板と比較して脱灰度の羑は著明であつて，かな り耐酸性の強いことが穊える(図 2 )。乞の組成が 無機質より成ることは斯る横断面歯牙を苛性カリ ーグリセリン液中で煮沸して有機質を除去する場

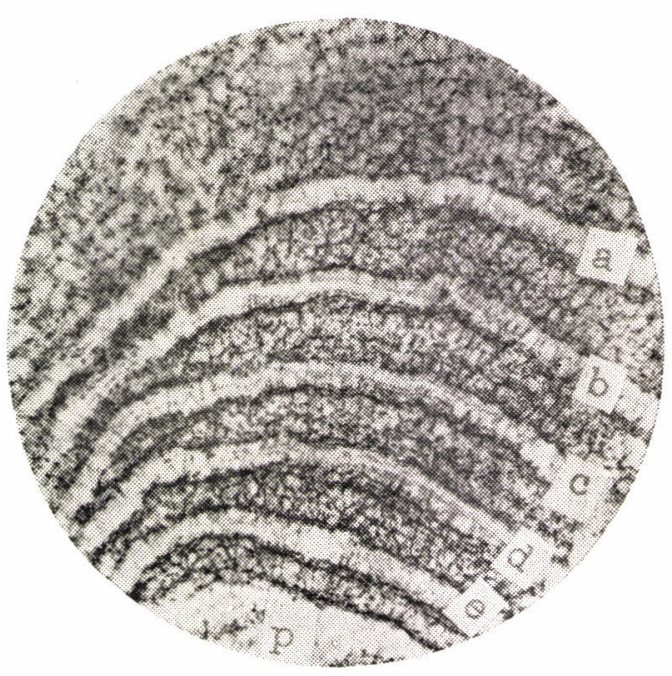

㘠 2 家鬼象牙質横断面 $0.5 \mathrm{mg} / \mathrm{kg}$ 弗素静注 2 日間隔 $\mathrm{a}, \mathrm{b}, \mathrm{c}, \mathrm{d}, \mathrm{e}$ : 弗素変質屠板 $\mathrm{p}$ : 歯䯣腔

合，その像が変らずにむしろ凸凹が明膫となる事 実から確実である。以上の実験は檕化曹達, 弗化 カリ及び硅弗化曹達の各々に就て試みたが何れも

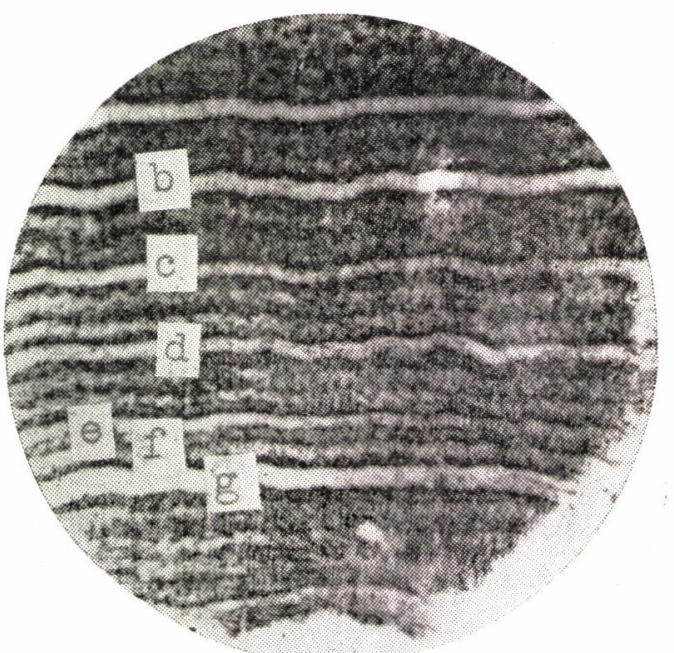

図 3 家鬼象牙質横断面

a. b : $0.5 \mathrm{mg} / \mathrm{kg}$ 弗素静注

c, d: $0.2 \mathrm{mg} / \mathrm{kg}$ 弗素静注

e, f : $0.1 \mathrm{mg} / \mathrm{kg}$ 弗素静注

$\mathrm{g} \quad: 0.5 \mathrm{mg} / \mathrm{kg}$ 弗素静注

$\mathrm{a}, \mathrm{b}, \mathrm{c}, \mathrm{d}, \mathrm{e}$ 各 2 月間隔

$e, f, g$ 連日 
作用強度に学は認められないので，以下の実験で は全て弗化曹達を使用することとした。

次㳊与する弗素量によつて変質層板の幅径及 び脱灰度に等のあることから，その出現する限界 量を決定することにした。 $0.1 \mathrm{mg} / \mathrm{kg}, 0.2 \mathrm{mg} / \mathrm{kg}$ ， $0.5 \mathrm{mg} / \mathrm{kg}$ 及び $1.0 \mathrm{mg} / \mathrm{kg}$ の弗素量を静注した が, $0.2 \mathrm{mg} / \mathrm{kg}$ 以上では 1 回の注射で確実に変質 層板の証明が出来, $0.1 \mathrm{mg} / \mathrm{kg}$ では殆ど認めるこ とがない。即ち静注による限界量は $0.1 \mathrm{mg} / \mathrm{kg}$ と $0.2 \mathrm{mg} / \mathrm{kg}$ との間にある(図 3 )。

更に 4 時間, 6 時間, 12 時間, 24 時間間隔に同量 弗素の静注を行い日周期層の幅径を基潐にして変 質層板の幅径を测定するに, $0.5 \mathrm{mg} / \mathrm{kg}$ 弗素量の 作用持続時間は 4 時間前後であることを知つた。

B）動注と静注との比較に就て

以上の如く弗素静注によつて出現する象牙質変 質層は，血中に入つた弗素イオンが直接造歯細胞 に作用して耐酸性大なる弗化カルシウム或は弗化 燐酸カルシウムの形成を行つたものと考学るが, 然らば頸動脈内注射を行つて多量の弗素を歯牙に 到達させた場合には更に強度の変質層板が見られ る䉪である。区之, 動注の場合に变質層板の出現 が弱いなら血中に入つた弗素は循環中に他の物質 と結合し，硬組織に沈着し易い形に置換されて後 に初めて歯牙に作用するものと考光られる。この 点を明らかにする為に同一家鬼に $0.5 \mathrm{mg} / \mathrm{kg}$ 弗 素を頸動脈内及び同側耳静脈内に夫々 24 時間以 上の間隔を置いて注射し，或はその間隔を換え， 又は順序を逆にして多数の家鬼に就て試み, 前述 の実験法に従つて観察を進めた。

全例に於て両者の善はなく，更に注射側歯牙許 りでなく反対側歯牙にも全く同程度の変質層板を 認めた。また股動脈内注射と静脈内注射との比較 に於ても全く同様の結果が得られた(図 4 )。

そこで注射速度を色々に換えて血液との接触時 間に変化を与光た場合の比較を行うこととし, 0.5 $\mathrm{mg} / \mathrm{kg}$ 弗素 (約 $2.5 \mathrm{cc}$ 溶液)を 10 秒, 20 秒, 30 秒, 1 分 及び 2 分 の注射速度で頸動脈内注射を 行つたが，変質層板の出現には何等の変化も認め ない。

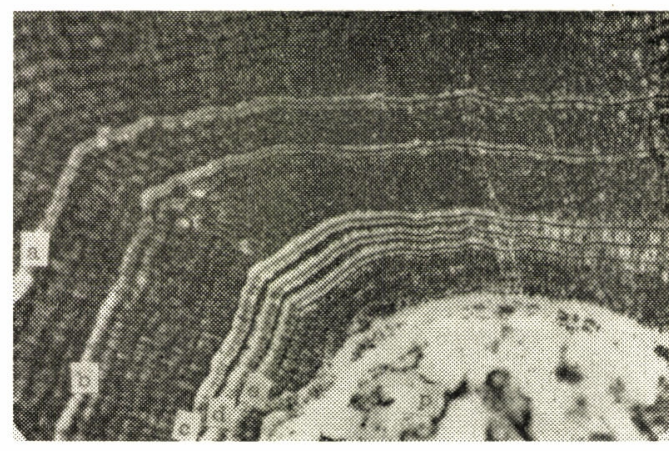

図 4 家鬼象牙質横断面

a, c, e : $0.5 \mathrm{mg} / \mathrm{kg}$ 弗素静注

b, d: $0.5 \mathrm{mg} / \mathrm{kg}$ 弗素動注

$\mathrm{a}, \mathrm{b} \quad 3$ 日間隔

c, d, e 連日

$\mathrm{p}$ : 歯髄腔

以上の結果から弗素は血中に於てその性質を変 化することなく，安定な弗化物又はイオンの形で 循環を続忷逐次造㐘細胞作用するものと考兄 る。動注と静注の比較に於て善の無いのは血液循 環速度から考兄て解決出来ることと思われる。

C）石死代謝との関係に就て

歯牙の石灰代謝機能を攪乱した時に劭素イオン の象牙質への介入は如何に変化するかを知る為 に, Acidosis 及び Alkalosis を起させた場合, 或 は絶食期, 更には甲状腺並びに上皮小体剔出後の 弗素変質層板に就て観察した。斯る体液変化に 伴う硬組織形成障害に就ては岡田・三村 ${ }^{9}$ 及び松 本 ${ }^{10)}$ 等の実験によつて既に確認されて居る。

0.1 規定塩酸 $5 \mathrm{cc} / \mathrm{kg}$ を 5 時間間隔で前後 2 回 腹腔内注射した後に, 弗素 $0.5 \mathrm{mg} / \mathrm{kg}$ を耳静脈内 注射する。之を 1 2 日間隔に行い, その前後に弗 素注射のみを行つて対照とした。その結果 Acidosis 飞よる石灭化不良状態に於子る変質層板は 正常時に見られるそれと全く同一で増強も減弱も 認められなかつた(図 5 )。

同様に $3 \%$ 重曹 $20 \mathrm{cc} / \mathrm{kg}$ を時間間隔で 2 回 皮下注射後 $0.5 \mathrm{mg} / \mathrm{kg}$ 弗素を静注したものに就 て観察したが，Alkalosis の場合には石灰化良好 な象牙質形成が行われるにも拘らず变質層板には 変化が現れない。 


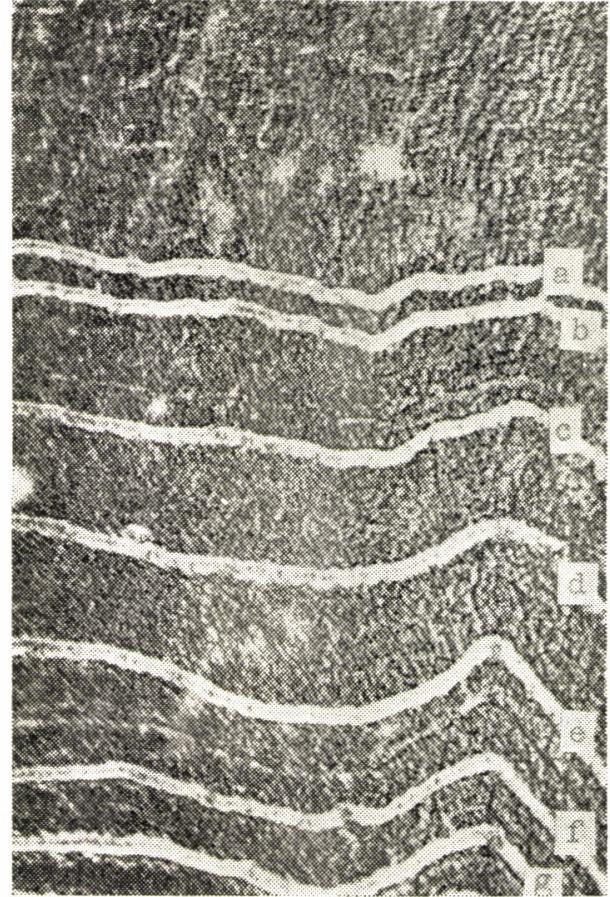

図 5 家鬼象牙質横断面

$\mathrm{a}, \mathrm{b}, \mathrm{d}, \mathrm{f}$ : 弗素静注のみ

$c, e, g$ ：塩酸注射後弗素静注

$a, b$ 連日

$b, c, d, e, f \quad 2$ 日間隔

$f, g \quad 1$ 日間隔

また家鬼を絶食させて弗素注射を続けても変質 層粄は正常時と変りなく, 更に数日間絶食させた 後に Vitamin $D_{2} 10$ 万 i. u. (Chocola D を使 用した） 1 日 2 回筋注を続けても変化はなかつ た。

更にまた训素 $1.0 \mathrm{mg} / \mathrm{kg}, 0.5 \mathrm{mg} / \mathrm{kg}, 0.2 \mathrm{mg} / \mathrm{kg}$ 及攵び $0.1 \mathrm{mg} / \mathrm{kg}$ を連日静注した蒙要の甲状腺並 びに上皮小体を剔出し, 手術日, 1 週後, 2 週後, 3 週後及び 4 週後より各々 4 日間前記弗素量を連日 静注乙術前, 術後の変質層板に就て観察を行つ た。術後全身状態の悪化する場合にも変質層板の 出現度には変化なく，幾分明確になる傾向もある が全般的に見て顕著な美は認められない(図 6 )。 術後種々なる時期に甲状腺 ホルモン Thyradin $1 \mathrm{cc}$ （日本薬局法甲状腺 $0.2 \mathrm{~g}$ に相当する）を連 日皮下注射した場合にも変化は見られなかつた。

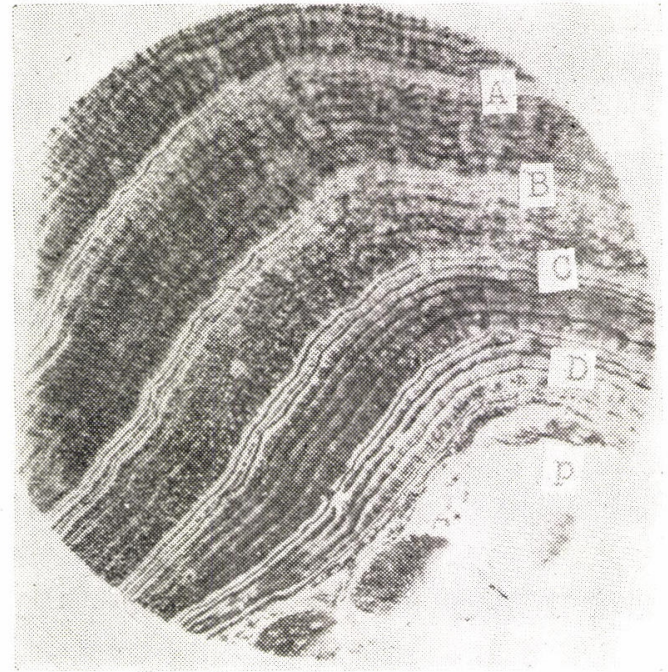

図 6 甲状腺及び上皮小体摘出家婜 象牙質横断面
A：術後 1 週弗素変質屠板
B： 術後 2 週弗素变質層板
C : 術後 3 週弗素变質層板
D : 術後 4 週弗素变質層板
$\mathrm{p}$ ：蹸艏腔

以上の如く血中に入つた帅素イオンは硬組織に 於ける石灰代謝の良否とは無関係に釆牙に到達 し, 造歯細胞に直接作用して歯牙形成障害を惹起 するものらしい。即ち変質層板の出現は血中に於 ける $\mathrm{Ca}, \mathrm{P}$ の変動伴う二次的結果とは考元ら れない。この点 Schour \& Smith ${ }^{4)}$ 及び Irving ${ }^{\text {7) }}$ の説に一致して居る。

\section{II. 歯髄內 Alkaline-phosphatase に及 ぼす影響}

弗素が酵素阻害性を有することは広く知られて 居るが，生体硬組織形成に重要な役割を果すと高

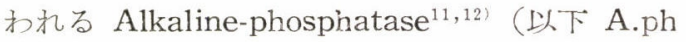
と略す）に対してどの様に作用するかを知る虑 に，㐘牙形成に直接関与寸る歯髄内Ａ．ph の消 長に就て㭘討した。実験動物には 2〜3 kg の成熟 白色家鬼を選び实験 1 に於て十分硬組織変性を惹

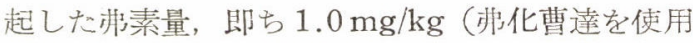
した）を 1 日 1 回耳静脈内注射を行い，2，5 万代 10 日間之を続けて最終注射 2 時間後に屠殺し, 直ちに歯牙を抜去, 破砾して歯䯣を摘出し，以下 
Gomori 法 ${ }^{131}$ そ従つて組織化学的検少を進めた。

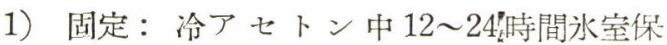
存, その後室温で 6 時間毎 2 回アセトン交換。

2） パラフイン包埋：脱水にはベンヂンを用 い30 分毎 2 回交換, パラフイン炘 $55^{\circ} \mathrm{C}, 2$ 時間以 内に包埋する。

3）切片：4８ルの連続切片とし，キシロー ル及びアルコールで脱パラフイン。

4) Incubation $2 \%$ Sod. barbital $25 \mathrm{cc}$ $2 \%$ Sod. $\beta$-glycerophosph.

$25 \mathrm{cc}$

$2 \%$ Calc. chloride $5 \mathrm{cc}$ $2 \% \mathrm{Mg}$. sulfate $2 \mathrm{cc}$ Aq. dest $50 \mathrm{cc}$

上記混合液中 $\left(\mathrm{pH} 9.1\right.$ 飞䘞正) $37^{\circ} \mathrm{C}, 1 \sim 2$ 時 間浸漬。

5）水洗 $\rightarrow 1 \%$ 硝酸コバルト中 5 分。

6）水㪇 $\rightarrow 1 \%$ 硫化了ンモン中 2 分。

7）水洗 $\rightarrow$ 脱水 $\rightarrow$ 封入。

A.ph は燐酸エステルを加水分解して燐酸を遊 離するエステラーゼであるから，組織より遊離さ せた燐酸にCa イオンを結合させ不溶性の燐酸塩 としてその位置に沈着させたものを更に硫化コバ ルトの形に置き挨えて可視的にする。A.ph 反応 ある部分は黒褐色汻色されるので鏡検は容易で ある。対照観察には Sod. $\beta$-glycerophosph.を 除いた混合液中で Incubation した試料を Hämatoxylin-eosin 重染色を行い両者を比較検討し た。

正常雪髄に於计るA.ph 反応は直接象牙質形成 渷与する関与歯細胞層に最も多く見られ，血管壁 が之に次ぎ，歯髄固有細胞には少量であつた（図 $7,8)$ 。州素注射 2 日目の所見では造歯細胞層に 軽度の A.ph 反応減芶索認めるが, その後 10 日 間連続注射しても減弱の度合飞変化はない。その 他の部分では更に軽度の抑制を認める程度であつ て，全体として歯髄内 A.ph に対する卯素の影響 は極めて僅かである(図 9 )。即ら微量势素の静注 は柬牙の石灰沈着㳗度の阻害作用を与えるが, 然し無機質結合体の変化によつてむしろ組成を強

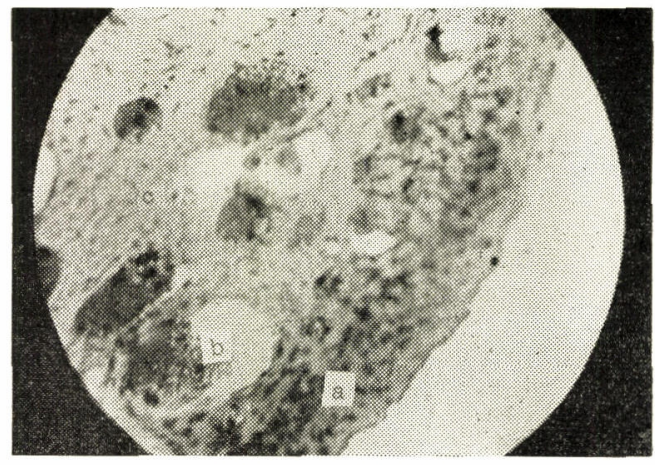

园 7 正常家鬼莯韨

(Hämatoxylin-eosin 染色)
a： 造雨細胞
b : 血管
c：菊髄固有細胞

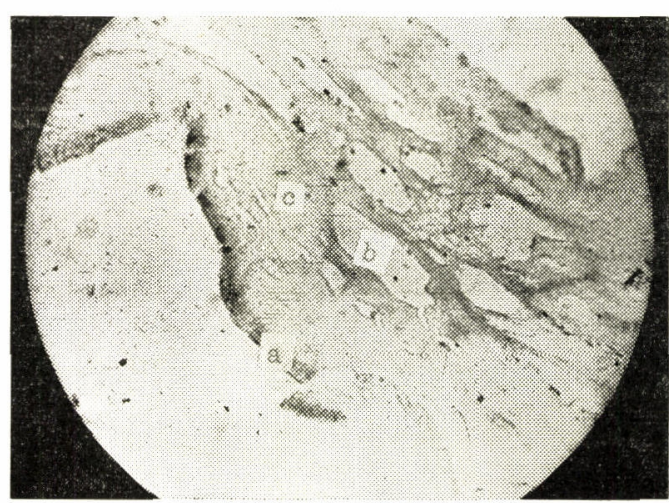

図 8 正常家鬼迷髄 (A. ph 反応)
$\mathrm{a} ：$ 造秚細胞
b : 血管
c：歯㬚迠有細胞

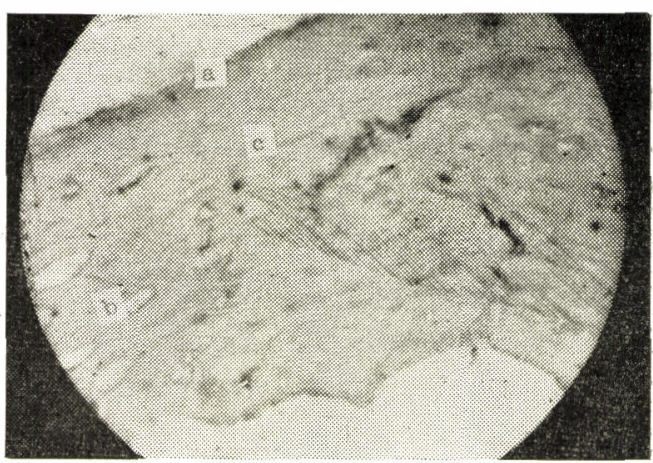

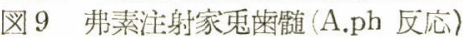
a : 造歯細胞
b : 血管
c：歯榷固有細胞 


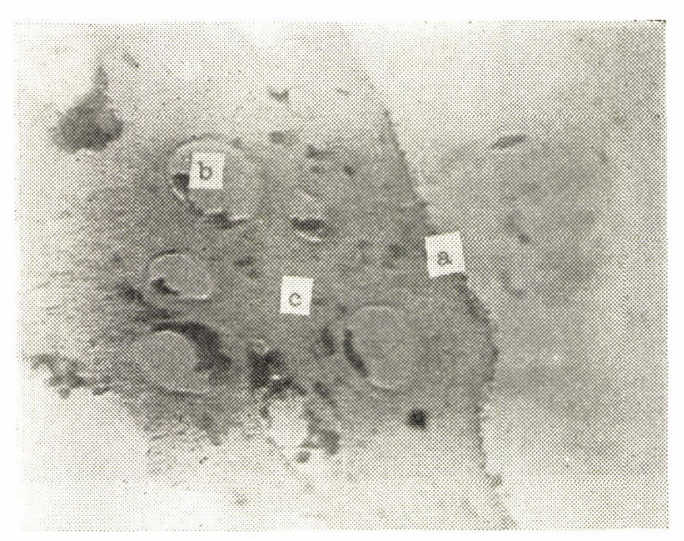

図 10 モ>沃度酷酸注射家鬼歯䯣 (A.ph 反応)
$\mathrm{a}$ ：造宷細胞
b : 血管
c：橉膸固有細胞

固にし耐酸性を賦与することの方がより重要な作 用点と考学られる。

一方また酵素毒であるモ>沃度醋酸は歯牙表面

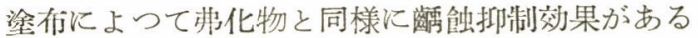
と言われて居るので14)，その A.ph に対する作用 を検討し弗素作用との比較を行つた。 $1.0 \mathrm{mg} / \mathrm{kg}$ モノ沃度醋酸の静注を連日行い前法同㥞に歯髄内 A.ph の定量を試みるに，極めて著明な抑制を認 めることが出来た(図 10)。即ち, 霜牙の石死代謝 にはかなり影響を齊らすものと考光られる。この ことは Grethe et al. ${ }^{15}$ が牛角に於ける実験で認 めている。然し乍ら斯る歯牙を実験 I の方法で鏡 検しても変質層板は全く見られないことから考光 て, モノ沃度醋酸に悃刢抑测効果があるとすれば 州嗉の如く歯牙耐酸性の増強によるものではなく 酵素毒的局所作用に因るものであろ る。このことは弗素の歯牙表面に於ける作用機転 解明に益するものであろう。

\section{III 硬組織への移行弗素量}

静注した弗素は直接画牙に到達してその石死化 機転に参画し硬組織組成に介入する事は以上の実 験から考光て十分予测出来るのではあるが，更に その確証を得る可く先人の業績 ${ }^{16-21)}$ 追試して体 内摂取那素量に就て硬組織移行の在否を確めた。

実験動物には $150 \mathrm{~g}$ 前後の同腹ウイスター系白 畄を選び，弗素 $2 \mathrm{mg}$ (苏化曹達を使用した)を 1
日 1 回 5 日間連続皮下注射 乙総量 $10 \mathrm{mg}$ 弗嗉を 摂取せしめ, 屠殺後, 上下顎前菌及び両側大腿悬 に就て定量を行つた。試料は70\%アルコール中 に 2 時間以上浸漬回定後，粉砕して歯髄及び骨 髄を可及的に除去し $500 \sim 600^{\circ} \mathrm{C}$ で 3 時間灼熱す る。次いで之を乳錸中で粉化し更に 2 時間灼熱し て有機質を完全に除いたものを定量試料とした。 州素定量法は Willard \& Winter の蒸溜法及び Sanchis の Zirconium-alizarin 比色法を夫及改 良して用いた222。测定值は全て $100 \mathrm{mg}$ Ash に 就ての弗素量をmg で示して居る。

表1 米牙及び肾の弗素量

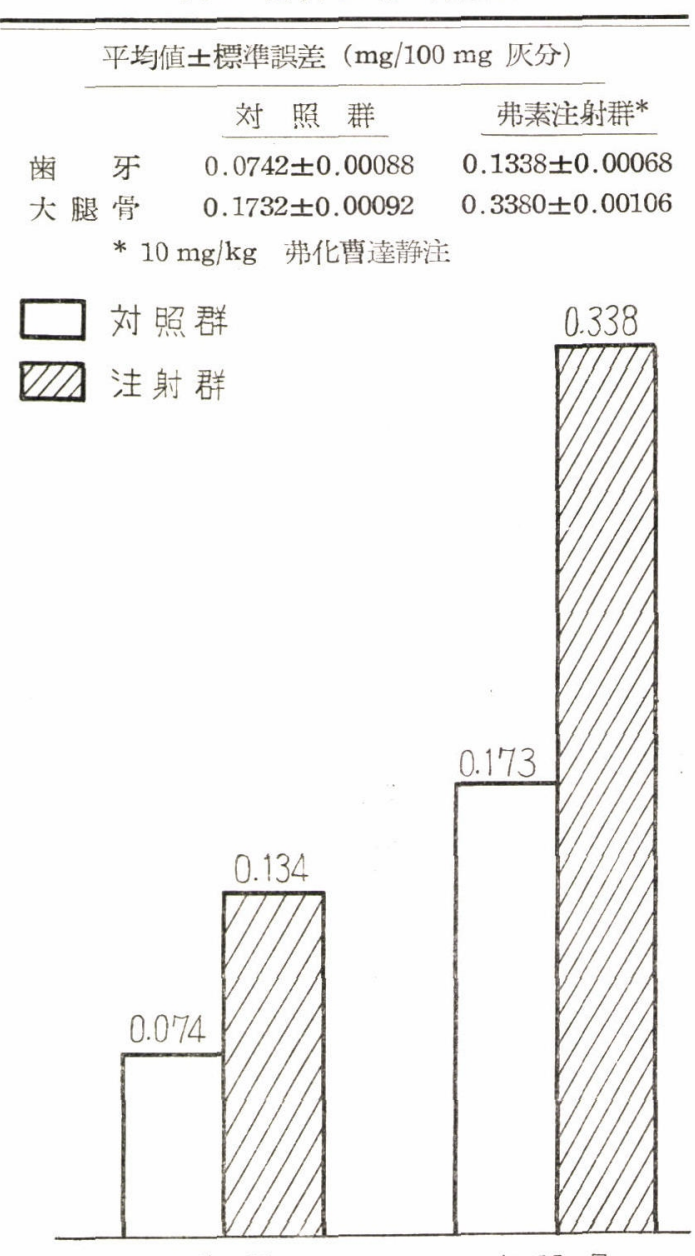

歯 牙 大腿骨 図 11 


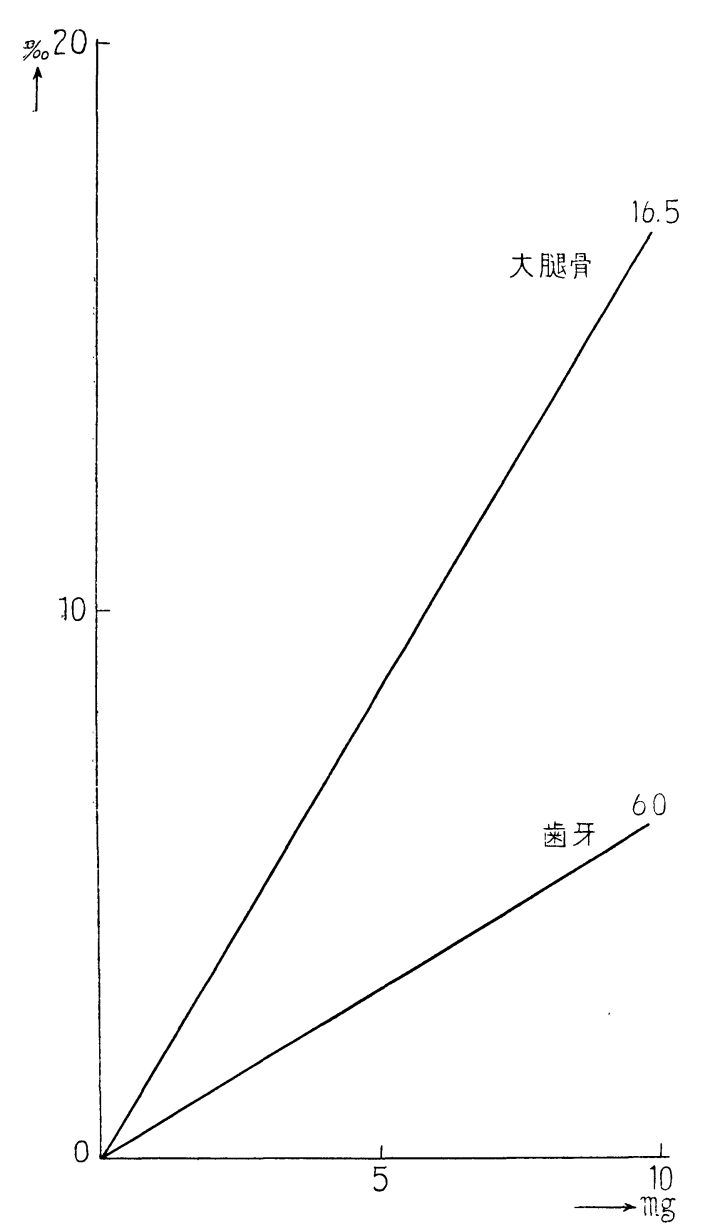

圀 12

歯牙の弗素量は対品群 $0.0742 \pm 0.00088 \mathrm{mg}$, 注 射群 $0.1338 \pm 0.00068 \mathrm{mg}$ で両者の間にはかな りの䇪が見られる。大腿骨に於ても対照群 0.1732 $\pm 0.00092 \mathrm{mg}$, 注射群 $0.3380 \pm 0.00106 \mathrm{mg}$ で更 に著しい差を認めることが出来る(表 1 , 図 11)。

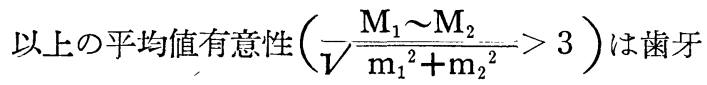
54，骨 118 で何れも有意であり，又 T-test（ $t=$

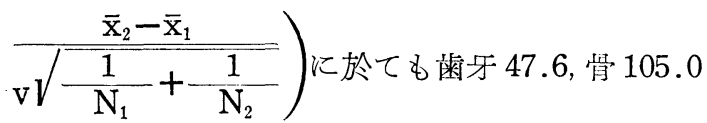
の $\mathrm{t}$ 值を示し, $1 \%$ 危険值 $\mathrm{t}=5.04$ 亿較べて数め て有意なることが確認出来る。10 mg 弗素の皮下 注射によつて歯牙及び大腿骨の弗素量は明らかに
增大を示して屌ることになる。然らば注射群值 より対照群值を䒴引いた量, 即ち歯牙及び大腿骨 へ夫々移行した卯素量は注射弗素量に対して如何 程の割合になるかを算定するに歯牙 $6.0 \%$ ，大腿

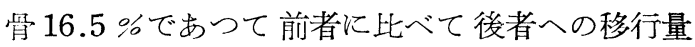
が遥かに多いことを知る(図 12)。

之等のことから血中に入つた非素の一部は形成 過程にある硬組織に到達し, その正常組成に変化 を与えることは確実である。

\section{IV 血液內弗素濃度の消長}

微量弗素の静注にも拘らずその作用時間が極め て長く持続することは既に変質層板幅径の测定に よつて観察したが，これに関連して血中を循環す る弗素量の時間的経過は如何なるものであるかを 知る為に次に実験を行つた。

実験動物には 2〜3 kg の成熟白色家忽を選び， 耳静脈より弗素を注入乙頸動脈を通過する血液弗, 素量に就て観察した。即ち弗素 $10 \mathrm{mg} / \mathrm{kg}$ （棜化 曹達を使用した） 1〜1.5 分の注射速度で一側耳 静脈より注入し, 注入終了直後及び 10 分, 15 分, 30 分, 60 分, 2 時間, 3 時間, 4 時間, 5 時間後に夫 々同側頸動脈より採血してその全血中弗素量に就 て测定する。弗素定量法は実験 III と同様 Willard \& Winter 法及び Sanchis 法を改良して行 つた。採血量は最初の 2 例は各 $10 \mathrm{cc}$ 宛, 後の 2 例は各 $5 \mathrm{cc}$ 宛であるが, 测定值は全て $10 \mathrm{cc}$ 血液 中肃素量を $\mathrm{mg}$ で示すことにした。

弗素注射 30 分前の同側頸動脈血を対照として 採血, 定量した。その弗素量は $0.091 \mathrm{mg}$ で注射 直後は $0.771 \mathrm{mg}$ の最高值を示し, その後は 30 分 以内に極めて急速な下降を行い $0.165 \mathrm{mg}$ となる が，㳄いで緩かな曲線を画いて下降を続け 4 時間 後には殆ど注射前の值に厌る(表 2, 図 13)。即ち 形素は安定な形で血中を循環し乍ら注射直後より 逐次硬組織形成を障碍するものであり，また 0.5 $\mathrm{mg} / \mathrm{kg}$ 弗素静注によつて出現する变質層板幅径 が 4 時間に相当することから考えて，血中弗素量 はかなり微量濃度に低下しても晌作用を持続する ものと思われる。

次に血中に於ける弗素が血液成分の变化を招き 
表2 血中弗素量

定 量 值 $(\mathrm{mg} / 10 \mathrm{cc}$ 血液 $)$

\begin{tabular}{|c|c|c|c|c|c|c|c|c|c|c|}
\hline \multirow{2}{*}{$\frac{\text { 注 射 前 }}{30 \text { 分 }}$} & \multirow{2}{*}{ 弗薪注射* } & \multicolumn{9}{|c|}{ 注 射 後 } \\
\hline & & 10 分 & 15 分 & 30 分 & 60 分 & 70 分 & 2 時時 & 3 時時 & 4 時間 & 5 時間 \\
\hline 0.072 & 0.760 & & & & 0.156 & & 0.106 & & 0.070 & 0.070 \\
\hline 0.102 & & 0.361 & & 0.166 & & 0.147 & & & & \\
\hline 0.100 & & & & & & & 0.130 & 0.107 & 0.102 & 0.101 \\
\hline 0.090 & 0.782 & & 0.242 & 0.163 & 0.156 & & 0.105 & & & \\
\hline
\end{tabular}

* $10 \mathrm{mg} / \mathrm{kg}$ 弗化曹達静注

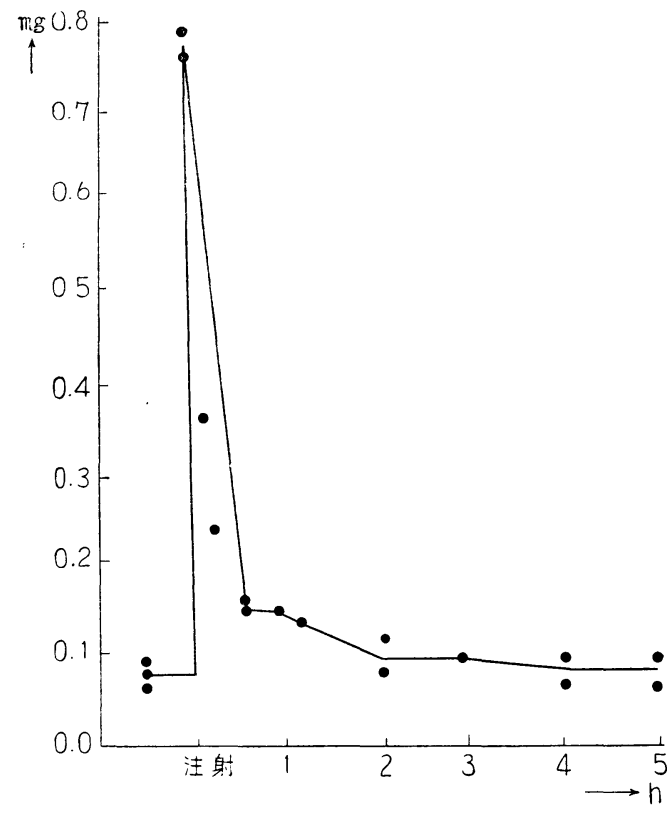

図 13

或は酵素系，ホルモン系の障碍を来すことは一応 考光得ることであるから，先ず血液成分との関係 表 3 全血及び血清中弗素量

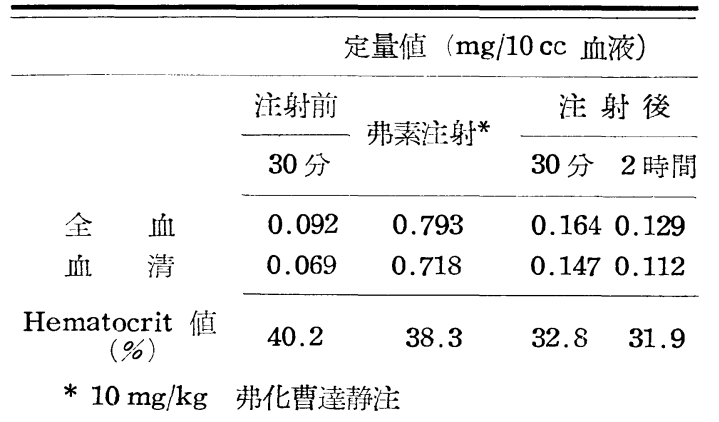

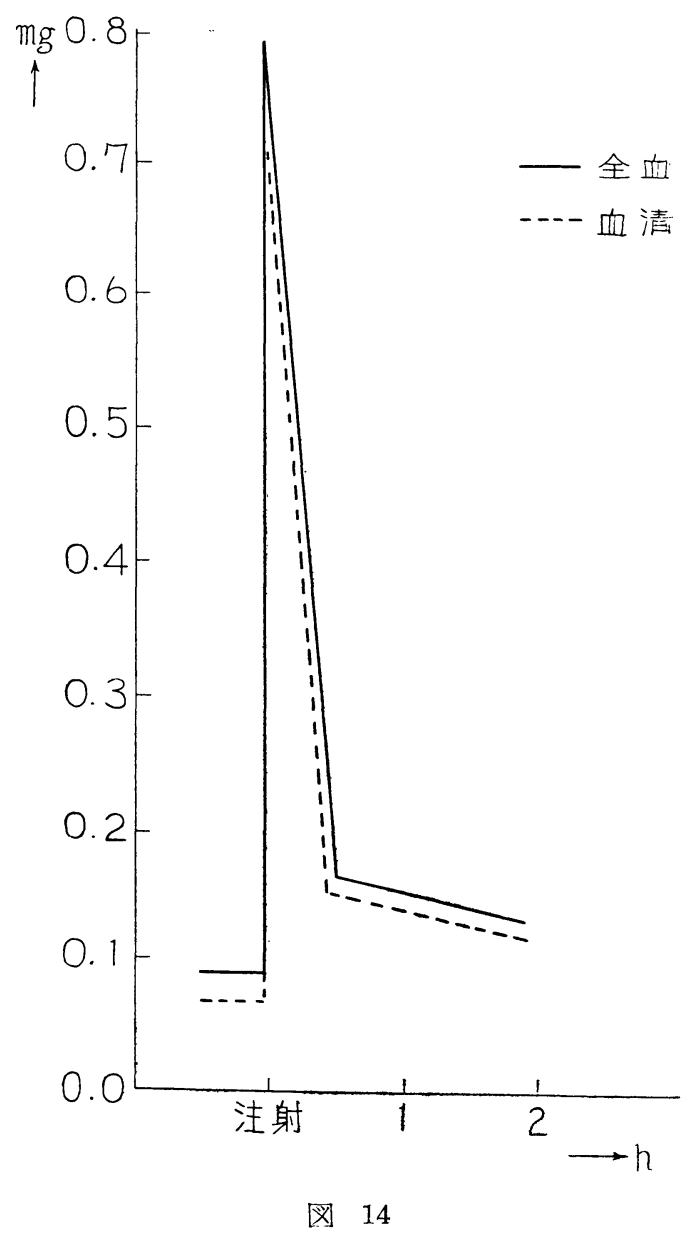

に就て実験を進めた。前実験と同様の方法で採血 したものに就て一部は全血の嚾，一部は分離した 血清のみに就て扐素定量を行い，血清部分と血球 部分の何れに重要な関係をもつかを確めた。採血 
による負担を軽減する為に 2 頭の家鬼より同時に 採血し両者を混合したものに就て定量した。血清 中弗素量は全血 $10 \mathrm{cc}$ 中の血清部に含をれる弗素 量のことで Hematocrit 测定值より計算して求 めた。

全血弗素量と同じく血清弗素量も注射直後に最 高値を示し，その後急激な下降曲線を画いて居る が, 血清内と血球内との割合から言つても注射直 後には血清弗素量はかなり増大して属る。即ち対 照に於て全血弗素量の $76 \%$ \%が血清内に含有され て居たものが注射直後に $90 \%$ に増加して居る(表 3, 図 14)。之は採血の反覆による Hematocrit 值 の低下にも起因するが，両者の絶対值に著しい篦 があることから考えて血清部分により多くの重要 性が秘められているものと思う。

\section{総括並びに考按}

Mottled teeth は地方病として現れる霜牙形成 不全症で，珠瑯稜柱間にある粘合質の不足まては 欠如が著明でその部分は白斑乃至着色玟として認 められ，また象牙質には球間象牙質の増加が見ら れる。之等のことは古くから観察 ${ }^{23-25)}$ されて局た のではあるが，その原因が版素含有飲料水の常用 によるものであると確認されたのは極めて近年の ことで，その後多くの研究者は実験的に州素原因 説の裹付を行つた ${ }^{26-28)}$ 。爾来この研究は益々盛に 検討されて来たのであるが，軽度の弗素中毒症に 於ては唃玲羅患が減少して居ることに着目され て以来, 研究の主題は弗素による哃刢子防へと漸 次移行する様になつた ${ }^{29-40)}$ 。硬組織の形成障碍を 惹起する薬物が一方で龄刢抑㸝作用をもつと云了 ことは一見かなり矛盾したものと考えられるが， 之を詳細に検討すれば次の様な仮説が成立するこ とは現在までに判明して居る。

1）口腔内細菌に対する抑制作用 ${ }^{41,42)}$

鳉玲発生に関与する連鎖状球菌, 乳酸菌に対す る殺菌力は in vitro で認められることが出来る。 事実, 弗素地带住民の口腔内細菌数は減少して居 ると云われる。然し乍ら礝玲抑制を齊らす湌料水 中弗素濃度では細菌に対する影響は殆ど見られな
W。

2）酵素毒的作用 ${ }^{43,44)}$

弗素に酵素毒作用のあることは知られて居るが 就中, 孷水化物の酸醱酵機転は著明に阻止される。 歯垢中に生じた酸によつて歯牙脱灰の開始される

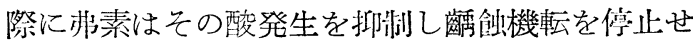

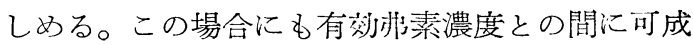
の開きがある。

3）歯牙の耐酸性獲得 45,56)

歯牙の無機成分は $\mathrm{Ca}, \mathrm{Mg}$ の燐酸塩及び 宸酸 塩であるが，扸素の介入によつて弗化カルシウム 或は弗化燐酸カルシウムが形成される。この形の 複塩は酸に対する溶解度が極めて低いので唃刢発 生による歯牙溶解が阻止される。

獦刢発生そのものが既に複雑な機構より成立し て佣ることから考えて，その抑制作用も単一のも のではなく, 少く共以上 3 説には夫々因子的可能 性が存在するものであろう。

以上の如く歯牙硬組織に及湆す弗素作用に就て は多くの研究が行われて来たのであるが，その殆 ど全てが菌牙表面よりの弗素吸着に就ての実験で あつて成長過程に血行路より介入する機序に関し ての研究は詳かでない。䆌刢発生が歯牙表面より 行われること，更に近年広く实施されて居る弗素

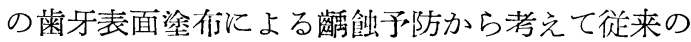
研究法は当を得たものではあるが，眽つて Mottled teeth の発生機転及び 水道水弗素化に着目 すればその解明法は不十分と云わねばならない。 硬組織汇取り入れられた脚素の組織学的証明法は 従来全く知られて居なかつたことがこの研究に大 きな障碍を齊らして居たのである。

最近，岡四・三村は歯牙硬組織に出現する縞模 様変化を追求することから橔めて簡単に打素介入 層板を証明したが，これは拈素研究の新しい分野 を開拓する意味に於て極めて意義あるものであ る。そこで私はこの方法を応用して家鬼象牙質に 出現する組織変化の詳縕を検討することにした。

版素注射時刻に形成される象牙質は耐酸性が増 強され，極めて Contrast の強い変質層板として 観察されるが，これは肟素イオンの介入によつて 
弗化カルシウム或は弗化燐酸カルシウムの形成が 行われた為と考える。乞の組成変化に就ては電子 顕微鏡的観察を行つて居るので詳細は他の機会に 発表する。

切慓本を通法に従つて Hämatoxylin-eosin 染色した場合に象牙質層板に変化の現れることは 既に報告されて居たのであるが，てれらは錸めて 粗雑な観察に過ぎず，殊に微量弗素の影響に関し ては不明であつた。嶓刢子防に效果のある飲料水 中濃度は 0.3 J至 1.0 p.p.m. と云う微量である が，本実験によつて $0.2 \mathrm{mg} / \mathrm{kg}$ 静注が霜牙変化 の限界量であることを明確てしたことは重要なこ とであろうと思う。

また変質層板幅径の筑から作用時間及び作用強 度を知ることが出来るのでその出現機序に就ての 種々なる考察が可能となる。先ず種々なる㸝化物 を同一の条件で別々に静注してその等を観察した が何れの場合にも全く同様な変質層板の出現をみ た。De Eds et al. ${ }^{57)}$, Smith et al. ${ }^{58)}$ 及び Mc Clure $^{59)}$ は州化物の種類によつて中毒症状に善の ないことを報告して居るが，歯牙変化に就ても同 じことが需える。

次に静注と動注との比較から血中を循環する弗 素が歯牙に到達するまでの変化の有無を検討し， 更に石灰代謝機能を掜乱した状態に於ける歯牙へ の弗素介入が如何なるものかに就ての実験を試み た。串素を摄取した場合，体液が酸性に傾き血中 $\mathrm{Ca}$ 量が低下して尿中及び唾液中 $\mathrm{Ca}$ 量の増加を 見るが，之は組織中の可溶性 $\mathrm{Ca}$ 塩を不溶性の形 に挨える為であつて之によつて全身碍障が惹起さ れるものである ${ }^{60,61)}$ 。斯る中毒症状は $\mathrm{Ca}$ 摄取量 と逆比例すると㝘われて扂る ${ }^{62,63)}$ 。この場合，歯 牙及で骨の $\mathrm{Ca}$ 量は增加, $\mathrm{P}$ 量は減少し従つて $\mathrm{Ca} / \mathrm{P}$ は増大すると言う報告もあるが64,65), 微量 版素の静注時には歯牙石灰化の良态と無関係に変 質層板の形成を認めることが出来る。即ち血中に 入つた形素は直接造霜細胞に到達して歯牙形成を 障碍するもので，血中 $\mathrm{Ca}$ 及び $\mathrm{P}$ の変動によつて 歯牙形成障碍を惹起するものではない。

然らば弗素が歯牙へ介入する際，幼若象牙質の
石灰化には如何なる作用を齋らすものかを知る為 に A.ph に対する影響に就て組織化学的観察を 行つた。Ph は含水孷素, 燐脂質及び核蛋白の如 く生体に於て重要なる物質の新陳代謝に関与する ことは衆知の事実であつて，殊に A.ph は硬組織 の石灰化に欠く可からざる因子であると言われて 居る。歯牙内 $\mathrm{Ph}$ に関しては既に多くの報告があ つて可成詳細な検討が 加えられて居るが 66-68), これに対する弗素の影響に就ては報告が少い。 Smith \& Lantz ${ }^{69)}$, Thomas et al. ${ }^{70)}$ 及び Roholm et al. ${ }^{711}$ は白鼡の実験で弗素投与によつて A.ph の抑制されることは極めて少いことを, 松 时・深川 ${ }^{22}$ は海猽に於てはアルカリ性及び酸性 $\mathrm{Ph}$ 共に著しい変化はなく実質細胞変性部に軽度 の減弱を認めて居る。その他何れの報告に於ても 弗素の A.ph に対する影響は極めて僅微であり, 私の実験に於ても又之等の実験と同一の結果が得 られた。

弗素の酵素阻害機転に就ては今日佮不明である が， $\mathrm{Mg}$ 及び Ca の酵素賦活性除去説がある。然 しながら摄取された弗素の大半は速かに排泄好分 されるので臟器組織の酵素機能を直接抑制する能 力は可成乏しいものと考皇る。

因みに Robison \& Rosenheim ${ }^{73)}$ は骨及び軟骨 に於ける正常石灰化機転に就て in vitro の実験 で次の如く説明して居る。

1） A.ph によつて燐酸エステルは加水分解を 受け組織液中に過剩の骨塩が出現する。

2）その度合が充分過剩に達した時に初めて組 織基質部に $\mathrm{Ca}$ 塩の沈着をみる。

この考え方からすれば州素は第 1 機転に殆ど影 響を及ぼさないが，造歯細胞に直接作用すること によつて第 2 機転に強い作用を与え Ca 塩に䏳素 の介入した異常不灰化畨を形成するものであろ 5 。

以上の如く体内に摄取され心叛素イオンは形成 過程にある歯牙硬組織价介することは確実であ るから，化学定量によつてその増加量を確認する ことが出来る筈である。人歯牙の固有弗素含有量 は $0.05 \%$ 前後で象牙質は珄瑯質より多量である。 
Mottled teeth は正常雬に比べて 2〜3倍の弗素 を含有すると言われ，また工場中毒者に於ては 10 倍にも増加したと報告されて居る74)。動物に弗素 を投与して組織内弗素量の増加を実験的に確めた 報告も既に見られて居る ${ }^{75,76)}$ 。骨は歯牙に比べて $2 \sim 3$ 倍多量に含有するもので77,78), 私の成績に 於ても静注弗素の移行量は $100 \mathrm{mg}$ Ash 当り 3 倍 近く骨の方が多くなつて屈る。然し乍ら生体内で 最も弗素の沈着すると言われる硬組織に於てさえ 投与量の極く一部の移行を認めるに過ぎないこと から考えて，その大半は速かに排泄されると思わ れる。

そこで弗素投与後の血中濃度は極めて急激な変 動を示すことが予想されるので，頸動脈を通過す る弗素量に就てその時間的経過を测定した。注射 直後に最高值を示す弗素量は 30 分後には約 $90 \%$ が血中より萕を消しその後約 4 時間をでは正常值 に比べて僅かに多量の弗素が循環を続けて居る。 之は $10 \mathrm{mg} / \mathrm{kg}$ 弗素静注時の测定值であるから， 変質層板の出現を齊らす $0.5 \mathrm{mg} / \mathrm{kg}$ 弗素の場合 には血中濃度は更に微量なものとなる訳である。 而もこの場合でさえ 4 時間前後も作用を続けて居 ることから考えて，歯牙に影響を劑らす血中弗素 濃度は極めて微量で充分なことが理解出来る。

他方，血中に於ける弗素は安定な状態を保ちな がら循環を続けるものらしいが，血液成分のどの 部分に親和性をもつかを知ることはその作用機序 の解明に必要な事と思う。白甪を张素含有食で飼 育すれば30日で Hemoglobin の一過性低下が見ら れ，血液変化は雪牙組織像の変化より早期に出現 すると言う報告 ${ }^{79}$ はあるが，血液組成との関係に 就ての研究は他に殆ど見られない。循環弗素量の 大半は血清中にあるもので，弗素静注によつて更 にとの割合を増加することを本実験に於て確認し たが，その後の分解及び解毒が如何なる機序で行 われるかは今後の研究に残された課題であろ.5。

\section{結論}

1. 微量弗素の静注によつて家鬼象牙質には耐 酸性大なる変質層板が出現する。之は注射時に形
成される象牙質層に弗素イオンが介入して弗化カ ルシウム又は非化燐酸カルシウムを構成する為で あろうと思われる。

2. 胰素イオンが確実に歯牙に移行して居るこ とは化学的定量実験より赛証出来る。

3. 血中に入つた拈素の大半は速かに排泄され るが，極めて微量の残部は倘安定な形で循環を続 け逐次造歯細胞に作用して歯牙に沈着する。この 際硬組織に介入する炜素は血中 $\mathrm{Ca}, \mathrm{P}$ の変動と直 接の関係がない。

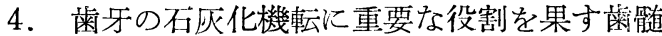
内 Alkaline-phosphatase に対しても弗素は殆ど 影響を及ぼさない。

稿を終るに当り終始御䅰篤なる御指導と御校閲を舓 わつた恩師真崎教授に満腔の謝意を捧げをす。

\section{交 献}

1) Sollmann T.: A Manual of Pharmacol. 7 : 804, 1949.

2) Eichler, O.: Heffters Handb. exper. Pharmakol. $10: 1032,1950$.

3) Greenwood, D. A.: Physiol. Rev. 20 : 582, 1940.

4) Schour, I. \& Smith, M. C. : J. A. D. A. 22 : 796,1935

5) 岡田・三村 : 日薬物誌. $29: 75, \S, 1940$.

6) Euler, H. \& Eichler, O. : Dtsch. Zahn-MundKieferhlk. 9 : 1, 1942

7) Irving, J. T. : J. D. Res. 28 : 144, 1949.

8) 岡田・三村: 日薬理誌. $48: 200 \S, 1952$.

9) 岡田 •三村 : 日薬理誌. $29: 71 \S, 1940$.

10）松本・日薬理誌. $50: 204 \S, 1954$.

11) Robison, R. : Biochem. J. 17 : 286, 1923.

12) Kay, H. D. : J. Biol. Chem. 89 : 249, 1930.

13) Gomori, G.: Am. J. Clin. Path. $16: 347$, 1946.

14) Massler, M.: Dentistry. 4 : 546, 1944.

15) Grethe, H. et al. : Naunyn-Schmiedebergs Arch. 214 : 398, 1952.

16) Klemment, R.: Ber. Dtsch. Chem. Gessellsch. 68, 2012, 1935.

17) Bowes, J. H. \& Murray, M. M. : Biochem. J. $29: 102,1935$.

18) Lowater, F. \& Murray, M. M. : ibid. 31 : 837, 1937.

19) Armstrong, W. D. : J. Biol. Chem. $119:$ V, 1937. 
20) Martin, D. J. : J. D. Res. $27: 27,1948$.

21) Myers, H. M. et ai. ibid. $31: 743,1952$.

22）篗田：口腔病学会雑誌 $20: 259,1953$.

23) McKay, F. S. \& Black, G. V. : Dent. Cosmos $58: 477,627,1916$.

24) Pierle, C. A.: J. A. D. A. $13: 999,1926$.

25) Smith, M. C. et al.: J. D. Res. $12: 149$, 1932.

26) Smith, M. C. \& Lantz, E. M. : J. Biol. Chem. $101: 677,1933$.

27) Dean, H. T. et al.: Pub. Health Rep. 49 : $1075,1934$.

28) Smith, M. C. et al.: J. A. D. A. 22 : 814, 817, 1935.

29) Dean, H. T. : Pub. Health Rep. 53 : 1453, 1933 .

30) Hodge, H. C. \& Finn, S. B. : Proc. Soc. Exper. Biol. \& Med. 42 : 318, 1939.

31) Bibby, B. G. : J. D. Res. 22 : 207, 1943.

32) Knutson, J. M. \& Armstrog, W. D. : Pub. Health. Rep. 62 : 425, 1947.

33) Keyes, P. H. \& Shourie, K. L. : J. D. Res. $28: 133,1949$.

34) Muhler, J. C. \& Day, H. G. : J. A. D. A, $41: 528,1950$.

35) Muhler, J. C. \& Day, H. G., J. Nutrit. 44 : 413, 1951.

36) Rickles, N. H. \& Becks, H. : J. D. Res. 30 : 757, 1951.

37) Massler, M. : ibid. 32 : 703, 1953.

38) Muhler, J. C. et al.: J. A. D. A. $46: 290$, 1953.

39) Muhler, J. C. \& Shafer, W. G. : Science 119 : 687, 1954.

40) Muhler, J. C. et al. : J. D. Res. 33:33, 1954.

41) Bibby, B. G. \& Vankesteren, M. : ibid. 19 : 391, 1940.

42) Dean, H. T. et al. : Pub. Health Rep. 56 : 365, 1941.

43) Miller, B. F.: Proc. Soc. Exper. Biol. \& Med. 39 : 389, 1938.

44) Eichler, O. et al. : Naunyn-Schmiedebergs Arch. 206 : 82, 1949.

45) Volker, J. F. : Proc. Soc. Exper. Biol. \& Med. 42 : 725, 1939.

46) Volker, J. F. et al. : ibid. $43: 643,1940$.

47) Gerould, G. H. : J. D. Res. 24 : 223, 1945.

48) Muhler, J. C. \& Van Huysen, G. : ibid. 26 : 119, 1947.

49) Zipkin, I. \& McClure, F. J. : ibid. 28 : 151, 1949.
50) Manly, R. S. \& Bibby, B. G. : ibid. 28 : 160, 1949.

51) Scott, D. B. \& Wyckoff, R. W. G.: Pub. Health Rep. 65 : 43, 1950.

52) Fischer, R. B. \& Muhler, J. C. : J. D. Res. $31: 751,1952$.

53) Muhler, J. C. et al. : ibid.31: 756, 1952.

54) Rathje, W.: ibid. $31: 761,1952$.

55）増原：日腔病学会雑誌 $20: 67,1953$.

56) Fischeret, R. B. al. : J. D. Res. $33: 50$, 1954.

57) De Eds et al.: Proc. Soc. Exper. Biol. \& Med. 31 : 824, 1933.

58) Smith, M. C. \& Leverton, R. H. : Ind. Eng. Chem. $26: 791,1934$.

59) McClure, F. J. : Pub. Health Rep. 65 : 1175, 1950.

60) Jodlbauer, A. : Naunyn-Schmiedebergs Arch. $164: 464,1932$.

61) Creenwood, D. A. et al. : J. Am. Vet. Med. Ass. 39 : 28, 1935.

62) Irving, J. T.: J. D. Res. $28:$ 17, 1949.

63) Massler, M. \& Schour, I. : J. A. D, A. 44 : 159, 1952.

64) Smith, M. C. \& Lantz, E. M. : J. Biol. Chem. $101: 677,1933$.

65) Sobel, A. E. et al. : J. D. Res. 28 : 61, 1949.

66) Harowitz, N. H. : ibid. $21: 519,1942$.

67) Greep, R. O. et al. : J. A. D. A. $36: 427$, 1948.

68) Morse, A. \& Greep, R. O. : J. D. Res. 31 : 284, 1952.

69) Smith, M. C. \& Lantz, E. M. : J. Biol. Chem. $112: 303,1935$.

70) Thomas, J. O. et al. : J. Pharmacol. \& Exper. Therap. 54 : 160, 1935.

71) Roholm, K. et al. : Proc. Soc. Exper. Biol. \& Med. $37:$ 376, 1937.

72 ) 松田・深川：東京医事新誌 70, 263, 1953.

73) Robison, R. \& Rosenheim, A. H. : Biochem. J. $28: 684,1934$.

74) Roholm, K.: Heffters Handb. exper. Pharmakol. $10:$ 1094, 1950.

75) Phillips, P. H. et al.: J. Nutrit. $10: 93$, 1935.

76) Volker, J. F. et al.: J. Physiol. 132 : 707, 1941.

77) Murray, M. M.: ibid. $87:$ 388, 1936.

78) Lawrenz, M. et al. : J. Nutrit. 20 : 383, 1940.

79) Matt, M. M. : J. D. Res. 32 : 667, 1953. 